\title{
EARLY ELECTRIC LIGHTING IN CAVES - POSTOJNSKA JAMA, SLOVENIA, 1883-1929
}

\section{PRVI PRIMERI ELEKTRIČNE RAZSVETLJAVE V JAMAH - POSTOJNSKA JAMA 1883-1929}

TREVOR R. SHAW ${ }^{1}$

${ }^{1}$ Karst Research Institute, ZRC SAZU, Titov trg 2, SI-6230 POSTOJNA, SLOVENIJA e-mail: izrk@zrc-sazu.si 
Abstract

UDC: 551.44:631.311.1(497.4)(091)

\section{Trevor R. Shaw: Early electric lighting in caves - Postojnska jama, Slovenia, 1883-1929}

After some preliminary attempts in 1863 , electric lighting was first used in Postojnska jama in 1883 for a visit by Emperor Franz Joseph. Alternative forms of bright light (lime-light in 1852, gas light in 1878) had been considered but not adopted. The permanent electric installation of 1884 was the third anywhere in the world. Its 12 arc lights were increased in later years. An "improved" system was fitted in 1901 but failed so often that it was replaced in 1906. An extensive new system was fitted in 1929. Errors in previous literature are corrected and much information published for the first time.

Key words: caves, lighting, electricity, lime-light, Slovenia, Schmidl, Postojnska jama.

Izvleček

UDK: 551.44:631.311.1(497.4)(091)

\section{Trevor R. Shaw: Prvi primeri električne razsvetljave v jamah - Postojnska jama 1883-1929}

Po prvih poizkusih 1863 so Postojnsko jamo prvič električno razsvetlili 1883, ob obisku cesarja Franca Jožefa. Najprej so poizkušali z različnimi močnimi svetili (“apnenčeva” luč 1852, plinske svetilke 1878), vendar se zanje niso odločili. Stalno električno razsvetljavo so vpeljali 1884, kot tretjo na svetu. Najprej so namestili 12 obločnic, kasneje pa so razsvetljavo razširili. "Izboljšan” sistem so namestili 1901, vendar je pogosto zatajil in so ga morali nadomestiti z drugim 1906. Popolnoma nov sistem so namestili 1929. V prispevku so popravljene napake iz prejšnjih objav, vsebuje pa tudi podatke, ki so prvič objavljeni.

Ključne besede: jame, razsvetljava, elektrika, apnenčeva luč, Slovenija, Schmidl, Postojnska jama. 
After some preliminary attempts in 1863, electric lighting was first used in Postojnska jama, for one day only, in 1883; and a permanent system was installed in 1884. Before that the normal lighting had been from oil lamps and candles, with occasional wooden torches, burning straw or fireworks (Shaw 2000, 39-41). The need for a brighter form of illumination was recognised as early as the 1850s when discussions about the possible use of lime-light took place in 1852 . Burning magnesium wire is known to have been employed to light the vast space of Veliki dom in 1866 (Henty 1866) and in 1878 gas lighting was considered as an alternative to the electric lighting which was already being investigated.

\section{OIL LAMPS AND CANDLES}

Torches or flambeaux made of wood split at one end and soaked with resin or wax had sometimes been used earlier but they produced a lot of smoke which blackened the stalactites so they were forbidden.

Oil lamps were certainly in use in the 1820 s, carried by the guides. A full lamp lasted for 5 or 6 hours so, to go as far as Kalvarija, beyond where the present underground railway stops, extra ones had to be carried. They were rather dim and visitors could pay for extra candles to be placed at certain points. From the mid 1850s the cave archives began to show large purchases of candles and their use was more formalised. Until 1858 the Murray Handbooks just referred to a separate charge made for "extra lights", whereas in 1867 candles were advertised for "small" or "great" illuminations. In 1861 it was reported that "Candles are fixed in wooden sockets in all the important parts of the cave, and are ready to be lighted at a moments' notice" (Comfort 1863). Another guide followed to extinguish them after the visitors had passed. A "small" illumination used $1,8 \mathrm{~kg}$ of candles and a "great" one 4,5 kg. Magnesium wire was sometimes used to light the largest chambers (Murray 1867, 449).

So much for visits on normal days of the year. Quite different was the illumination for the Grottenfests, held one a year from 1820 or 1821 and twice each year since 1857 . The cave was closed for ordinary tours and a band was present for dancing between 3 p.m. and 6 p.m. in what is now Kongresna dvorana. The whole cave was brightly lit; between 5730 and 8470 lights, either candles or oil lamps, were used on these occasions according to records in the archives. Similar lighting was provided for important state visits. Thus in 1857 and 1883 the Emperor had about 16.000 lights and a British royal party in 1887 was greeted by 38.000 candles and lamps in addition to the new electric lighting.

\section{LIME-LIGHT AND GAS LIGHT}

Before electric lighting was used in the cave in 1880 s, other sources of light had been seriously considered.

Some 30 years earlier the idea of lime-light, as later used in theatres, had been put forward by Dr Adolf Schmidl. Invented by Thomas Drummond (1797-1840), this produced a brilliant light by making a block of lime incandescent in an oxy-hydrogen flame. The lime dissociated at $900^{\circ} \mathrm{C}$ into calcium oxide and carbon dioxide. The gases were obtained by electrolysis of water, 
using an electric generator, but could be brought into the cave in iron bottles. Schmidl (18021863) was already well known in the region for his cave explorations and publications, and two years later he was to write the first book ever to treat all aspects of cave study as a single discipline (Schmidl 1854). He had this to say in an unpublished letter (Schmidl 1852) written just before 12 July 1852 to Ludwig Baron Mac-Neven O’Kelly, the chairman of the Postojna cave management committee.

Thus came my thought... that Drummond lighting in the cave could be much better than any other... It is without doubt that such intense lighting would exceed all expectations in [Veliki dom] or [Kalvarija]. I talked about this with the physics professor [J. Ferdinand] Hessler who fully concurs with me and even co-produced the experiment with me. The apparatus is... easy to operate. It consists of two iron vessels, one of which contains oxygen and the other hydrogen. When the gases mix they can be lit and then they pass over a piece of lime and produce this wonderful light... To operate the apparatus requires only the opening of a valve and lighting the gas with a match, and that can be done by any boy. Every apothecary can supply enough gases for 24 hours continuous lighting at a cost of not more than 4 gulden. Thus the lighting is much cheaper than candles.

The question is obtaining the apparatus, for which the engineer estimates a cost of 200 to 300 gulden. My friend Professor Hessler would himself supervise the construction and come with me to Postojna to install it. Considering the substantial wealth of the cave, I propose that you should order the apparatus to be made. For the cave to be illuminated with Drummond [lime-] light would be news that would create excitement all over Europe. Advertising it in Trieste and Ljubliana even for only one Sunday would cause so many visitors to come that one day would cover all the costs...

Permit me, your honour, to recommend this matter most urgently to you. If you let me know your decision, the apparatus can be made before I leave and I can bring it with me.

Lime-light was intensely bright, just as was the electric light of the1880s. Had it been used successfully in 1852 it might have delayed the need for electrical illumination. No action, however, seems to have been taken by the cave management at that time.

Another form of bright non-electrical illumination was used in caves as early as 1859 when an incandescent coal-gas lighting system was put in the English cave of Poole's Hole (Porteous 1950, 76). The archives of Postojnska jama show that such a scheme of gas lighting was being considered there in 1878 .

\section{ELECTRIC LIGHT}

It seems that some very early attempts to use electric light had been made in Postojnska jama in 1863, for a newspaper report (Anon 1863) of a visit by more than a thousand people on 29 June of that year stated that "on Belvedere another attempt was made with electric light". It is likely that this used an electric battery, like the 1880 Jenolan experiment referred to above. To have run cables all the way from the entrance as far as Belvedere (more than a kilometre) just for a trial is unthinkable. No more information has been traced in the cave archives; nor is anything known of the previous 1863 attempt mentioned. 
Electric lighting was first used practically in Postojnska jama for a special occasion in 1883 and a permanent installation was fitted in the following year. These are described in detail below but first they are placed in the context of similar events elsewhere, for the Postojna lighting of 1884 was the third permanent installation in any cave in the world.

Electricity had been tried as an experiment in the Jenolan caves of Australia on 22 July 1880 , using a $700 \mathrm{~kg}$ electric battery (Dunkley 1986, 48). This led to permanent electric lighting there in 1887 (Wilkinson 1888, 141), but before that such lighting had been installed in 1881 at Luray Caverns in USA and in 1883 at Kraushöhle near Gams in Austrian Styria. Luray had "numerous electric lights operating by a dynamo near the railway station" and was certainly in use before 11 October 1881 (Anon. 1881; Hovey 1882, 166-167; Ammen 1890, 17). The Kraushöhle lighting was first used there on 11 May, and was switched on every Sunday throughout the summer (Anon. 1883a).. The Postojnska jama lighting of 1883, detailed below, was used only on 15 July of that year, but the permanent Postojna system came into use on 25 May 1884 as the third one anywhere in the world not the second as stated hitherto. One week later, on 1 June, Olgahöhle in Germany received electric light (Zeigler et al. 1972), to be followed in 1887 by Dobšinska jaskyňa (Slovakia) and Jenolan caves (Australia).

As early as 1872 many tourists were complaining that the cave lighting was not bright enough, especially in the large chambers of Veliki dom and Kalvarija (Anon 1872). Then in 1880 an English visitor to Postojna, John Aubertin, used a magazine article to campaign vigorously for electric light at Postojnska jama.

It seems... incredible that the Austrian government, to whom the Cave belongs, should allow so stupendous and unique natural marvel to be so miserably and meanly served. Mere candles, to any number, are a mere farce... (Aubertin 1880)

In fact the cave management had been seriously considering the possibility of using electric lighting since 1878 when a manufacturer in Paris was approached.

\section{THE 1883 TEMPORARY INSTALLATION}

On 15 July 1883 a state visit to the cave by Emperor Franz Joseph was the occasion of electric lighting first being used there. Much wrong information has been written about this. The facts given here are taken from a reliable contemporary document, and the origin of some of the later errors is explained.

Lapajne $(1907,27)$ reports that the cave was then "partly lit by electricity". This can be expanded by information in an invoice dated 25 July 1883 from the firm of C. Denng \& Co., engine manufacturers of Wien, now in the archives of Postojnska jama (Fig. 1). It records the installation of three electric lamps with reflectors in the Tanzsaal (Kongresna dvorana) and connecting them to the "machine". No mention is made in the invoice of providing this power source; nor would it have been sensible to bring a heavy engine and dynamo from Wien when they could no doubt be hired locally. No documentation for this survives. The system was only temporary, for the imperial visit alone, and the equipment was returned to Wien immediately afterwards. The lights seem to have been incandescent lamps ("Lampen") not arc lights ("Bogenlampen") such as were used in the following year. In any case it was by this first electric lighting in Kongresna dvorana that the Emperor watched the traditional dancing, drank his glass of pikolit wine and 


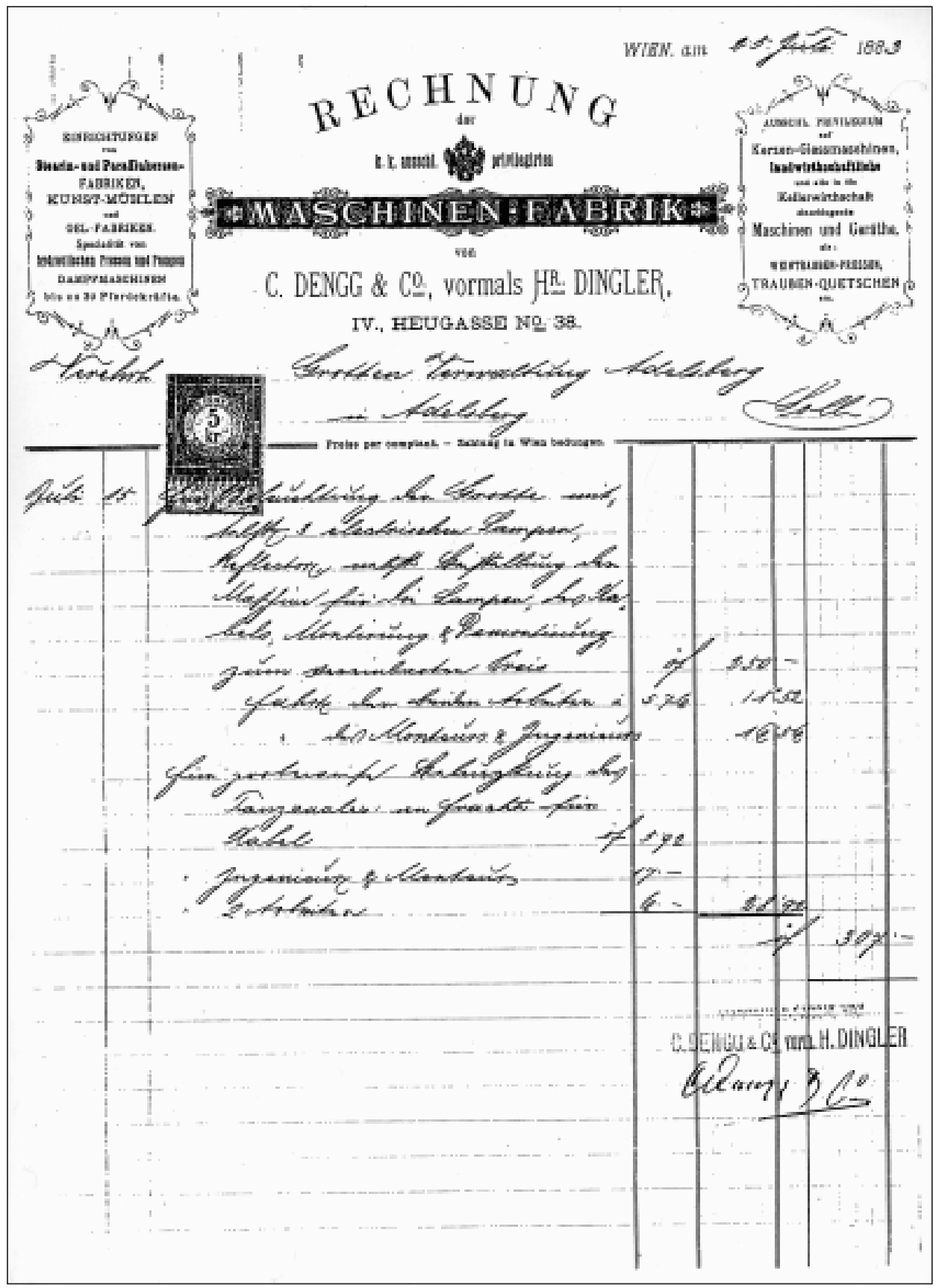

Fig. 1: Invoice from Dengg \& Co. of Wien, for electric lighting equipment hired by Postojnska jama in 1883 for the Emperors' visit. 
signed the visitors' book (Shaw \& Čuk 2002, 32).

The Denng invoice makes no mention of electric lighting in Veliki dom, but a newspaper (Anon. 1883b) reports that it contained "three mighty chandeliers that spread their magical electrical light." The text is quite clear about this but perhaps the reporter had become confused.

A statement by Habe \& Sajevic $(1960,11-12)$ that the lamps were connected to a direct current dynamo using three uninsulated wires may will be true but it must be regarded as suspect. These authors do not give their source for the information and other "facts" given by them for 1883 have been taken from Lapajne's (1907, 37-38) account of a different installation, the permanent one of 1884 .

The story of the 1883 temporary system has been dogged by further errors. Even the normally reliable Lapajne $(1907,49)$ writes that it contained 14 arc lights, probably a confusion with the 12 arc lights of 1400 candlepower that he correctly reports elsewhere for the 1884 installation. Some of these mistakes have been perpetuated by Binder (1983), Hazslinszky $(1999,83)$ and also, regrettably, Shaw \& Čuk $(2002,32)$.

Whilst no doubt this special illumination for the imperial visits was indeed to honour the Emperor, it also provided good publicity for the cave. It must, too, have given useful experience before the next year's permanent system was ordered.

\section{THE 1884 FIRST PERMANENT INSTALLATION}

As already mentioned, plans for permanent electric lighting had been under consideration since 1878. Besides a steam engine to drive the dynamo, offered then by the Syndicat d'Études d'Éclairage Électrique of Paris, water power was also thought of. The problem here was that the summer flow of the Pivka river was often too small. Nevertheless as late as January 1884 the Ljubljana firm of G. Tönnies proposed a dual power source - a water turbine (which would also drive a saw mill) for cheap power whenever possible and a steam engine supplied from a separate boiler for other times.

The scheme finally chosen used a "locomobile" (a self-propelled engine with boiler and a separate power drive) driving a dynamo. A plan (Fig. 2) in the cave archives shows this installation. There were two dynamos, a water tank supplied with water pumped from the river, coal bunker, work bench and operators' room, besides the locomobile itself, all in a wooden shed near the cave entrance. Approval was given by the Austrian Ministry of the Interior, Finance and Agriculture and the contract for the entire installation was placed with Siemens and Halske of Wien. The budgeted price of 14.000 gulden was spent on the equipment listed in Fig. 3, and some other items, including labour, freight, building materials and oil, brought the final total to 18.255 gulden.

The exact position of the engine house (Fig. 2) is not known but it was evidently quite close to the main cave entrance. A month before the lighting system was complete and switched on in May, a newspaper (Anon. 1884a) reported: "They have started to dig and make foundations for the building to house the electrical generating machinery near the river to the left of the road below the cave entrance... The system will be installed under the supervision of an engineer who will come from Wien." The arrangement in Fig. 2 is consistent with this location, with the water supply on the side away from the road. It indicates that the building was close to the road and 


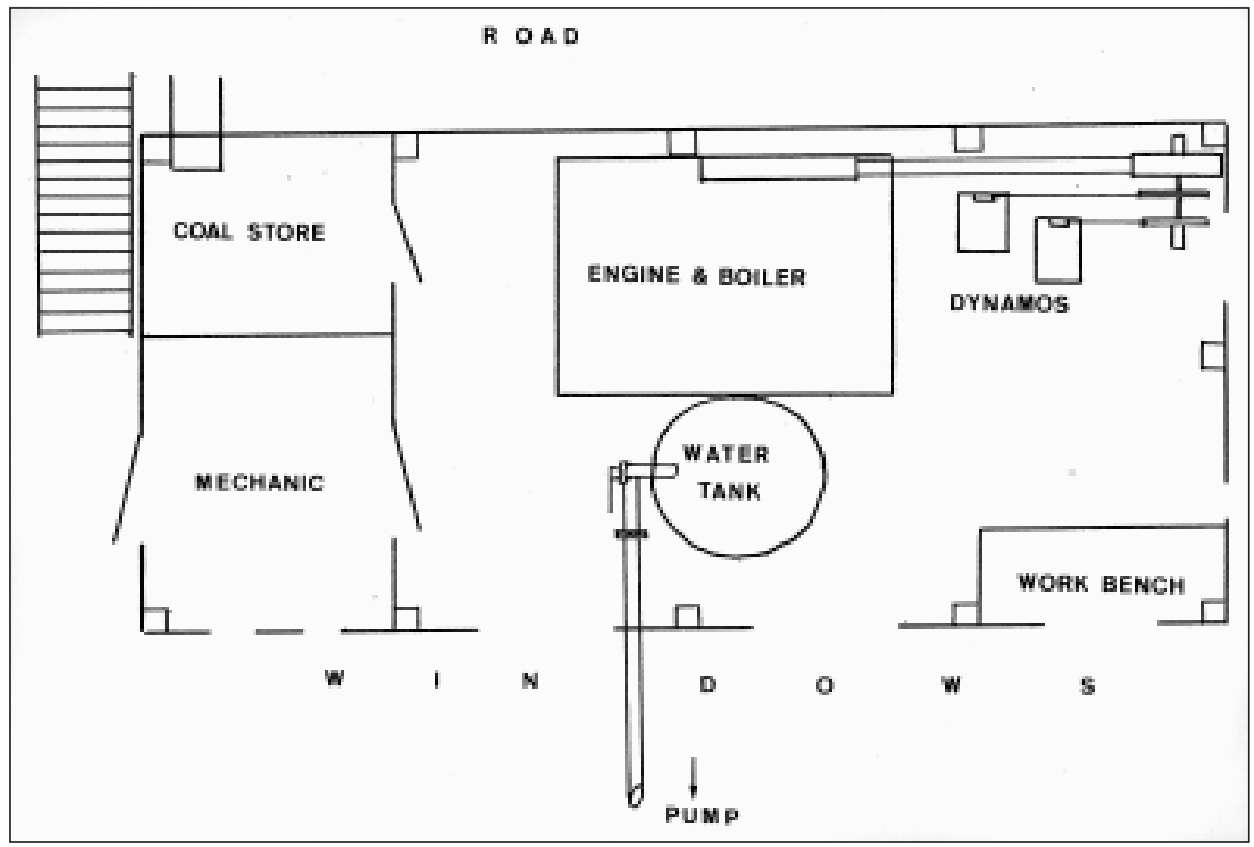

Fig. 2: The electric generating equipment outside the entrance in 1884, redrawn from a plan in the archives of Postojnska jama.

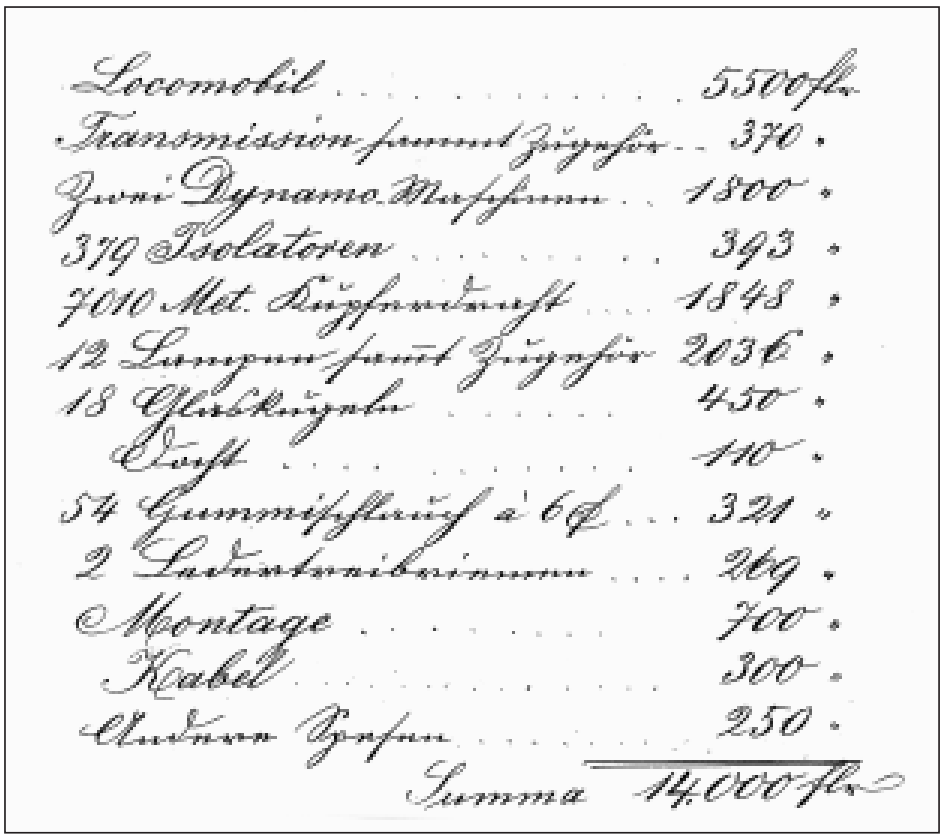

Fig. 3: Equipment bought in 1884 for the first permanent lighting system in the cave, from Globočnik's unpublished record (1881-1907, 152). 


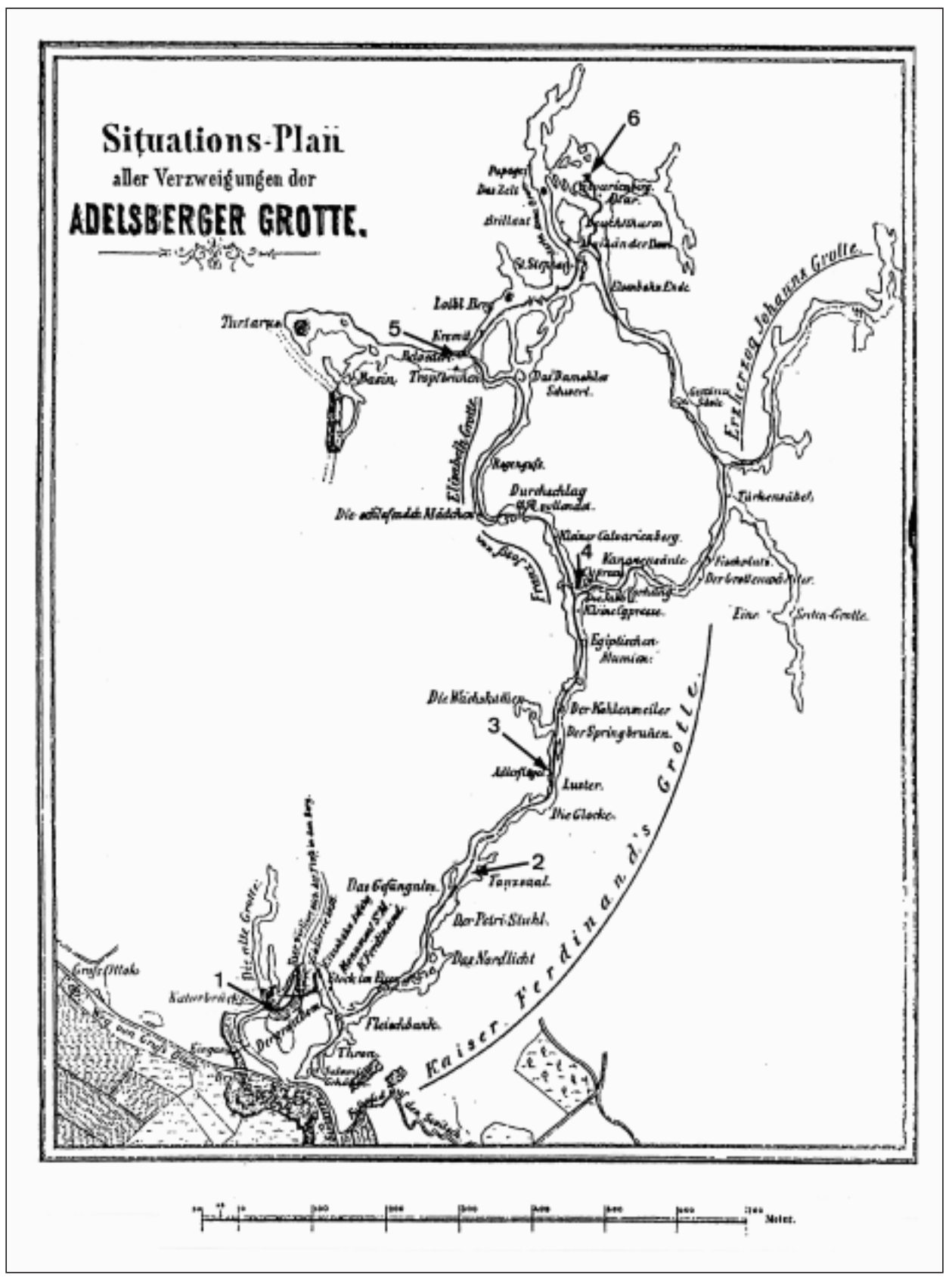

Fig. 4: A plan of the cave (Adelsberg 1889) marked to show the locations of the arc lights in 1884: 1. Veliki dom; 2. Kongresna dvorana; 3. Eagle's wing; 4. Tomb at Razpotje; 5. Belvedere; 6. Kalvarija. 

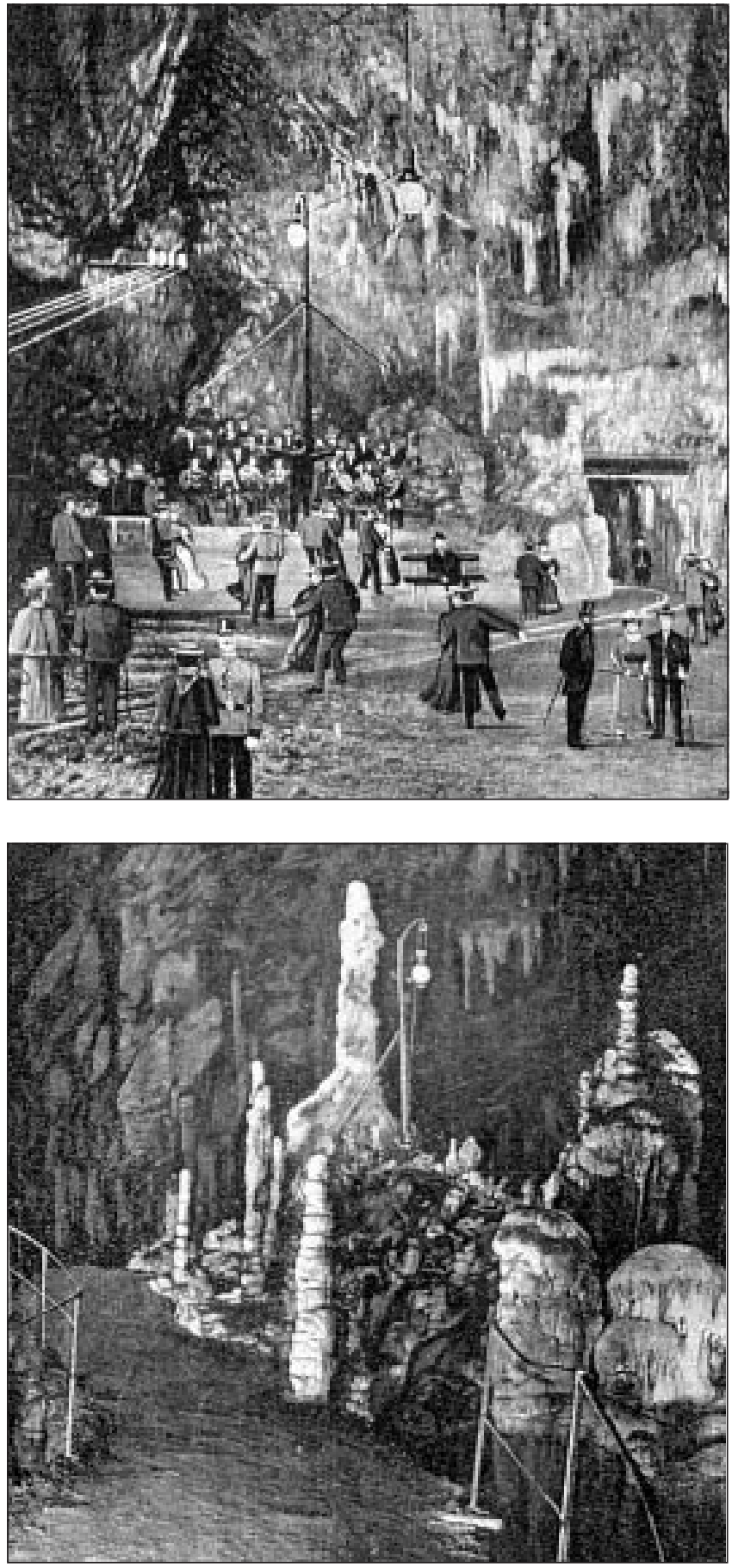

Fig. 5: A Grottenfest in what is now called Kongresna dvorana, showing two of the arc lights and their overhead wiring fitted in 1884. From a postcard used in 1903.

reached from it by going down the steps. The original plan in the archives shows that the ground fell away on the other three sides, so it must have occupied a shelf near the top of the slope running down to the river.

Illumination was from a total of 12 arc lights of 1400 candlepower each. These were placed (Fig. 4) in Veliki dom, Kongresna dvorana (then the Tanzsaal, Fig. 5), a calcite curtain then called the Adlerflügel (Eagle's Wing) on the west side of the main passage about $200 \mathrm{~m}$ north of Kongresna dvorana, the Grab (Tomb) near Razpotje where Male jame meets Stara jama, the Belvedere and Kalvarija (Fig. 6). Twelve lamps in six places; the figures in brackets below represents the author's estimates of the most probable number of lamps at

Fig. 6: An arc light on Kalvarija. From a photograph on a postcard of about 1900. 
each place. Clearly the Adlerflügel (1) and the Grab (1) in the passage would have only one each. Pictures (Fig. 5) show two in Kongresna dvorana though there may have been three as bright lighting was needed for the Grottenfests (2 or 3 ). The Belvedere could use two but one would be enough (1). Kalvarija would benefit from more than the one in Fig. 6 (2). And Veliki dom would need all it could get (4 or 5). The light at the Grab was coloured green (Anon. 1884b), perhaps to reduce its brightness in the relatively small passage. The supply to the lamps was all by overhead wires (Fig. 5). As will be seen from the problems experienced with underground cables after 1901 , this was evidently a wise decision.

The lights were first used on 25 May 1884 during a visit by the directors, professors and students of the Austrian Naval Academy near Rijeka. The date was given as 24 May by Lapajne $(1907,38)$, but the entry in the cave visitors' book is clearly dated "25/5" (Fig. 7) and the newspaper report (Anon. 1884b) was written on that day. Moreover, another newspaper (Anon. 1884c) states clearly that the visit took place on the Sunday, which was the $25^{\text {th }}$. The 200 or so people had nearly reached the Belvedere using normal lighting when "suddenly the place glowed brightly in electric illumination" (Anon. 1884b). On two days in the following week, local people from Postojna and district were allowed in free in the afternoon to see the new lighting (Anon. 1884c).

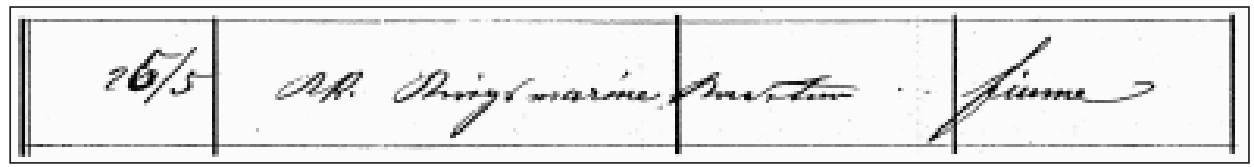

Fig. 7: The visitors' book entry for the cave visit by the K. K. Kriegs Marine Akademie (Austrian Naval Academy) from Fiume (Rijeka) on 25 May 1884, the day on which the new electric lighting system was first switched on.

When, on 2 June, the Whitsun grotten-fest was held under electric light for the first time, more than 6.000 people were present. The newspaper writer (Anon. 1884d) was ecstatic: the visitors "were moved to cheers, highly satisfied and full of praise for the fairy palace that had hosted them". Certainly the immense Veliki dom with the underground river flowing at the bottom can never have been seen clearly before, and to see "the moving mass of dwarf-sized people deep below on the bridge over the Pivka" for the first time must indeed have been memorable.

The sources used for this account, besides the cave archives and newspapers, are the manuscript records of the then cave director (Globočnik 1881-1907, 151-153) and Lapajne's (1907, 3739) history.

The 12 arc lights were only a start, and by the time Prince George (later King George V) of Great Britain came to the cave on 17 September 1887 there were 40 of them (George 1887). He was told that they were of 1360 candlepower each, probably a more accurate figure than the 1400 quoted above. Certainly by 1901 , immediately before the new lighting system was installed in that year, there were enough "to light all the parts of the cave that are seen" (Matthieu 1901, 189).

According to the guidebook (Baedeker 1888, 412) the lighting was switched on at 10 a.m. every day in the season from May to September and admission was then at a flat rate of $2 \frac{1}{2}$ gulden per person, in contrast to the complicated charging system used previously which depended on the number of guides and candles used. Already from June 1884 the cave was to be open with electric lighting (from. 10.30 a.m. at first) for the rest of the season (Anon. 1884e). 
Whilst the new lighting undoubtedly made the wonders of the cave easier to see, it also destroyed some of the mystery of the place and not everyone liked it. As Sir Richard Burton, the African explorer and orientalist then British consul at Trieste, wrote in 1887 "the world-famous caves were spoiled by the electric light, and we who had known the weird and subterranean state, deeply regretted the [loss of the] old wax candles" (Burton 1893 2, 347).

\section{1}

As technology advanced and visitor numbers (and receipts) generally continued to rise, thoughts were given to an improved electric lighting system. Perhaps, too, others shared Burton's misgivings about the glare of the arc lights which must have been quite unsuitable in the smaller passages. An undated cave plan (Wolich n.d.) of the 1890s proposed using 135 metallic filament lamps totalling 57.775 watts all along the route of the railway, over Kalvarija, through Koncertna dvorana and back along Male jame. It was evidently not adopted.

Then in 1901 a completely new system was installed with 977 low power carbon filament incandescent lamps supplementing 36 arc lights of about 2000 candlepower each (Lapajne 1907, 49-51; Sartori 1931, 98). The district governor Wilhelm von Laschan, who was also the director of the cave, had a central electrical control station built which enabled the electric generator outside the cave to supply not only the lights in the cave itself but also those in Postojna and the machinery of the towns' pumping station. A contemporary plan (Fig. 8) shows the distribution of the arc lights in the cave. Only 30 are marked, so Lapajne's figure of 36 may be the result of a misprint.

Fig. 8 also shows the location of the engine house, about $135 \mathrm{~m}$ from the main cave entrance. Its site is immediately south-east of the 2002 entrance building for the Speleobiological Station, between the cliff and what was until recently the south-east entrance to the Jama shop Pod Skalco (information from Oskar Ščuka). Another map held by the Postojnska jama management shows a separate pump house on the opposite side of the road, providing water from the river. The electric cables entered the cave through the natural entrance into what would later be the Speleobiological Station. To avoid having unsightly overhead wires in the cave, underground cables were used. These caused problems because the insulating sheathing of that time, made of natural rubber and woven silk, was unable to withstand the conditions for long. After less than two years in service the lighting failed while a large group of tourists was in the cave, and this was not an isolated incident for there were repeated flashes and other power failures. The reputation of the cave suffered whenever candles had to be used as substitute illumination and as Lapajne $(1907,50)$, who was cave director by then, feelingly said: "the disappointed cave visitors expressed themselves in not exactly flattering terms".

Fig. 8: The 1901 electric lighting system in the cave, from a plan by the manufacturers, Siemens \& Halske of Wien (scale 1:2880). The cable going south-east from the Maschinenhaus (engine house) is the supply to Postojna town. The Speiseleitung, drawn in red, are the main supply cables from the dynamo to the junction boxes, from which the arc lights are fed by the blue Bogenlichtleitung cables. The green Verteihlleitung supply the incandescent lamps. (on page 201) 


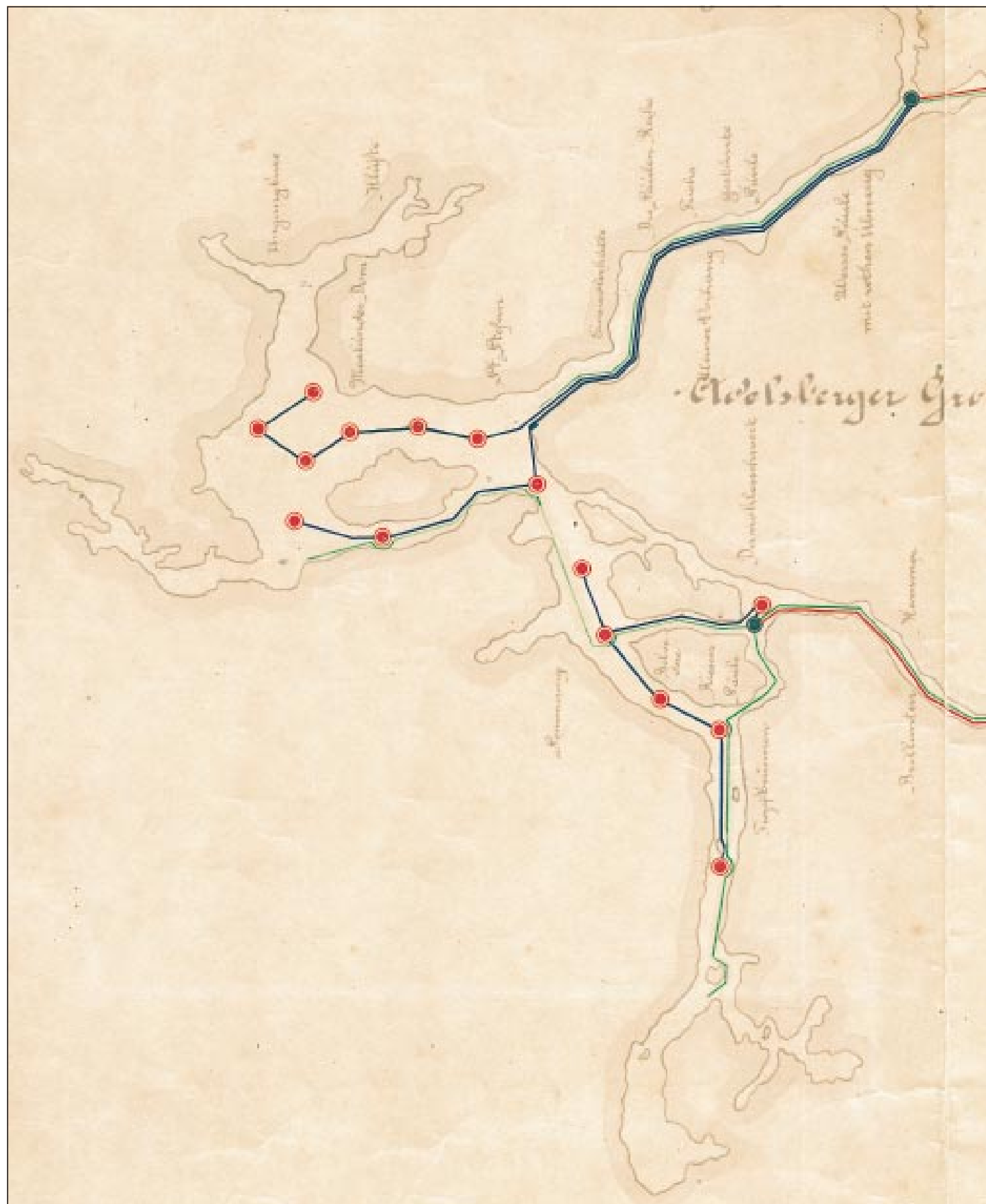


The cave management had to think seriously about a radical solution to stop the failures once and for all. After much research and consultation they decided upon overhead wiring again, as there had been before 1901. The underground cable was removed during the winter of 1905-06 and overhead copper wires installed in the following summer. The supplier of the new wiring (Vereinigte Elektrizitätswerke - Aktiengesellschaft) bought the rejected old cable and paid 1300 kroner for it in addition to providing the new wire, greatly to the advantage of the cave.

Additional information on these problems and their solution was added in Lapajne's handwriting at the end of Globočnik's unpublished Chronik (1881-1907, 177-187).

\section{9}

The system was again replaced in 1929, this time by an up-to-date one designed by Giuseppe Sartori, professor of engineering in Bologna University, who wrote a detailed technical description of it (Sartori 1931) with a cave plan showing the location of every one of its 522 incandescent lamps. These ranged from 40 watts, used in the artificial tunnel connecting Crna jama to the main Postojnska jama, to $2000 \mathrm{~W}$ used in large spaces such as Veliki dom, Kongresna dvorana and Koncertna dvorana. The greatest number were between $100 \mathrm{~W}$ and $500 \mathrm{~W}$. In all, they consumed $164.600 \mathrm{~W}$ of power and were distributed through almost the whole cave including Pivka jama and Črna jama, Lepe jame and the then new Speleobiological (then called Biospeleological) station. Some of the lamps were provided with special reflectors to give indirect lighting off the cave roof.

Further details are not given here because the installation is fully described by Sartori and no new research has been required.

\section{ACKNOWLEDGMENTS}

Above all I am indebted to Egizio Faraone of Trieste, who drew my attention to the 1852 Schmidl letter proposing the use of lime-light in the cave and who transcribed Schmidl's handwriting into modern script. Alenka Čuk read through several drafts of the paper, making many useful suggestions and providing several additional newspaper references of importance. Rudy Reinbacher of California, as so often, has translated lengthy passages from Globočniks' and Lapajne' records as well as the Schmidl letter. Tomislav Kajfež of Narodni muzej in Ljubljana searched issues of the Laibacher Zeitung newspaper and provided copies. Maja Kranjc also responded to the usual last-minute requests for information.

Illustration credits:

archives of Postojnska jama: 1, 7, 8; Karst Research Institute, Postojna: 3; private collection: 5, 6.

\section{REFERENCES}

[Ammen, S.Z.], 1890: The caverns of Luray ... an illustrated guide book.- Allen, Lane \& Scott, p. 47, Philadelphia

Anon., 1863: Novice, 8 July, Ljubljana. 
Anon., 1872: Novice, 22 May, Ljubljana.

Anon., 1881: The Luray caverns excursion.- The Reading Times \& Despatch, 13 October, summarized in The Journal of Spelean History, 36 (2) of 2002, 64, Monument, Colorado

Anon., 1883a: Pfingstfest in der Krausgrotte.- Mittheilungen der Section für Höhlenkunde des Oesterreichischen Touristen-Club,[2] (2), 12-13, Wien.

Anon., 1883b: Slovenski narod, 18 July, Ljubljana.

Anon., 1884a: Električna razsvetljava v jami.- Slovenec, 23 April, Ljubljana.

Anon., 1884b: Laibacher Zeitung, 27 May, 1024, Ljubljana.

Anon., 1884c: V Postojnski jami.- Slovenski narod, 29 May, Ljubljana.

Anon., 1884d: Laibacher Zeitung, 3 June, Ljubljana.

Anon., 1884e: Slovenski narod, 14 June, Ljubljana.

Adelsberg, 1889: Beschreibung der weltberühmten Adelsberger Grotte in Krain.- R. Schäber, p.55, Postojna.

Aubertin, J.J., 1880: The cave of Adelsberg.- The Graphic, 25 December, 664, London.

Baedeker, K., 1888: The Eastern Alps, including... Carniola... Handbook for travellers, $6^{\text {th }}$ edn.Baedeker \& Dulau, p. xxii, 492, Leipzig \& London.

Binder, H.,1983: Hundert Jahre elektrische Beleuchtung von Schauhöhlen.- Mitt. Verb. dt. Höhlen.u. Karstforschung, 29 (3-4), 50-52, München.

Burton, I., 1893: The life of Captain Sir Rich ${ }^{d}$. F. Burton, K. C. M. G., F. R. G. S.- Chapman \& Hall, 2 vols., London.

Comfort, G. F., 1863: The cave of Adelsberg.- The Ladies' Repository, 23 (10), 588-590, Cincinnati.

Dunkley, J. R., 1986: Jenolan Caves as they were in the nineteenth century.- Speleological Research Council, p. 59, [i], Sydney (p. 48, citing the file of newspaper cuttings P.37a in the Mitchell Library, Sydney).

George, 1887: King George V's diary.- Manuscript in the Royal Archives at Windsor Castle.

Globočnik, A., 1881 [- 1907]: Chronik der Adelsberger Grotte. Manuscript SAZU 35200 S in the Karst Research Institute, Postojna, p.[229].

Habe F. \& J. Sajevic, 1980: Razvoj osvetlitve turistične Postojnske jame in njen vpliv na druge turistične jame v svetu.- Življenje in tehnika, 9, 10-17, Ljubljana.

Hazslinszky, T., 1999: Anfänge der elektrischen Höhlenbeleuchtung.- Slovenský Kras 37, 81-90, Liptovský Mikuláš.

[Henty, G. A.], 1866: The Grotto of Adelsberg.- The Standard, no. 13164 for 14 October, 5, London.

Hovey, H.C., 1882: Celebrated American caves, specially Mammoth, Wyandot, and Luray ...Clarke, p. XII, 228, Cincinnati

Lapajne, S., [1907]: Aus der Chronik der Adelsberger Grotte.- Kleinmayr \& Bamberg, p. 62, Ljubljana. Publication thus in pamphlet form may have occured in 1907 or 1908; the content first appeared in 1907 as a series of articles in the Laibacher Zeitung newspaper.

Matthieu, 1901: A travers l'Italie, l'Autriche, la Suisse et l'Alsace.- Fischbacher, p. 429, Paris.

Murray, J., 1867: Handbook for travellers in Southern Germany... $10^{\text {th }}$ edn.- Murray, p. xii, 633, London.

Porteous, C., 1950: Caves and caverns of Peakland.- The "Come-to-Derbyshire" Association, p. 104, Derby.

Sartori, G., 1931: Il nuovo impianto di illuminazione elettrica nelle R.R. Grotte Demaniali di Postumia.- Le Grotte d'Italia, ser. 1, 5 (3), [97] -117, Trieste. 
Schmidl, A., 1852: letter written about 12 July to [Ludwig] Baron [Mac-Neven O'Kelly].- [2] ff., in the archives of Postojnska jama, at the Karst Research Institute, Postojna.

Schmidl, A., 1854: Die Grotten und Höhlen von Adelsberg, Lueg, Planina und Laas.- Braumüller, 2 vols., Wien.

Shaw, T. R., 2000: Foreign travellers in the Slovene karst 1537 - 1900.- Založba ZRC, p. 244, Ljubljana.

Shaw, T. R. \& A. Čuk, 2002: Royal and other noble visitors to Postojnska jama 1819 - 1945.Acta Carsologica 31 (1), supplementum I, p. 106, Ljubljana.

[Wilkinson, G. S.], 1888: Geological Survey of NewSouth Wales, Report of progress for 1887.Annual Report of the Department of Mines, New South Wales for 1887; 137-141, Sydney.

Wolich, F., n.d.: Übersicht der Adelsberger-Grotte.- unpublished plan in the archives of Postojnska jama, at the Karst Research Institute, Postojna.

Ziegler, M., et al., 1972: Die Olgahöhle in Honau.- Abhandlungen zur Karst- und Höhlenkunde, Reihe A, Heft 7, 11-14, München.

\section{PRVI PRIMERI ELEKTRIČNE RAZSVETLJAVE V JAMAH - POSTOJNSKA JAMA 1883-1929}

\section{Povzetek}

Ko so 1884 napeljali v Postojnsko jamo električno razsvetljavo, je bil to tretji primer take stalne osvetlitve na svetu. Leto pred tem so tak sistem vpeljali v jami Kraushöhle v Avstriji, nekaj pa je bilo le začasnih poizkusov, kot sta bila že dva pred tem tudi v Postojnski jami.

1852 so predlagali uporabo "apnene luči”, vendar predlog ni bil sprejet. 29. junija 1863 so Belveder razsvetlili z električnimi lučmi na baterije. 15. julija 1883 so ob obisku cesarja Franca Jožefa v Kongresni dvorani namestili tri močne električne luči, a so jih takoj nato spet odstranili. Pri vhodu v jamo je bila lokomobila, ki je poganjala generator, od njega pa so vodili kabli v jamo. $\mathrm{V}$ prispevku so popravljena prejšnja napačna poročila o tej razsvetljavi.

Stalno električno razsvetljavo so prvič vključili 25. maja 1884. Med Veliko dvorano in Kalvarijo je bilo na šestih mestih nameščenih 12 obločnic, vsaka po 1.400 sveč. Z elektriko sta jih napajala dva generatorja, ki ju je gnal parni stroj. Vse skupaj je bilo nameščeno v leseni lopi blizu jamskega vhoda. Do 1887 so število luči povečali na 40 in v sezoni je bila jama vsak dan električno razsvetljena. Nekateri obiskovalci so pripominjali, da ta bleščeča razsvetljava kvari občutek skrivnostnosti.

1901 so vpeljali popolnoma nov električni sistem, kjer so bile, poleg obločnic, številnejše, a šibkejše luči. Nova strojnica je bila 135 m od jamskega vhoda in kabli so vodili skozi današnjo Biospeleološko postajo. Od tod je dobival elektriko tudi trg Postojna. Kabli so bili napeljani v tleh, a zaradi slabe izolacije je večkrat prihajalo do izpadov, zato so jih 1906 zamenjali z bakrenimi žicami, napeljanimi nad tlemi.

1929 je bil vpeljan spet popolnoma nov sistem po zamislih profesorja strojništva iz Bologne. Namesto obločnic so namestili 522 žarnic od $2000 \mathrm{~W}$ pa do $40 \mathrm{~W}$ v ozkih prehodih. Takrat so končali predor v Črno jamo in tako je dobila električno razsvetljavo tudi Pivka jama.

(Prevedel A.K.) 